\title{
Exploration on the Understanding of Organ Donation Activities Among Muslims in Kuantan
}

Mohamad Firdaus Mohamad Ismail ${ }^{1}$, Muhammad Firdaus Roslan ${ }^{1}$, and Siti Zuhaidah Shahadan ${ }^{1 *}$ ${ }^{1}$ Kulliyyah of Nursing, International Islamic University of Malaysia, Pahang, Malaysia ${ }^{2}$ Hospital Pakar An-Nur, Selangor, Malaysia.

\begin{abstract}
Introduction: A common treatment for patients nearing the end of their life expectancy is organ donation and transplantation. Organ donation can cure diseases and save the lives of those who need them. End-stage organ failure patients must have an organ transplant in order to survive and return to a normal life. The most common obstacle to organ donation is finding a donor willing to save other people's lives. Muslims are less likely to donate organs because of a lack of understanding of organ donation activities. To devise a strategy, it is necessary to gain a better understanding of organ donation activities. The purpose of this study is to examine the perceptions of Kuantan's Muslim population regarding organ donation.

Methodology: Based on interviews, this study employs a qualitative approach. An in-depth interview was conducted with eight residents of Kuantan, Pahang, in a semi-structured manner. There was a thematic analysis of the data.

Results: Among the topics discussed were understanding organ donation, decision-making factors, the current updates related to organ donation activities in Malaysia, awareness of Islamic guidelines related to organ donation, and a source of information.

Conclusion: Due to misunderstanding and anxiety, the willingness to register as a donor is still lacking. As a result of awareness campaigns, family and friends can all positively influence organ donation. The Islamic view on organ donation should be conveyed to the public in an easy-to-understand manner by religious leaders.
\end{abstract}

Keywords: Living donors; Organ transplantation; Islam; Cadaver; Informed consent

\section{*Corresponding author}

Dr. Siti Zuhaidah binti Shahadan

Department of Medical Surgical Nursing,

Kulliyyah of Nursing,

International Islamic University Malaysia,

Jalan Sultan Ahmad Shah, 25200 Kuantan,

Pahang, Malaysia.

E-mail: sitizuhaidah@iium.edu.my

\section{Article History:}

Submitted: 09 August 2021

Accepted: 18 January 2022

Published: 31 January 2022

ISSN: 2600-898X 


\section{INTRODUCTION}

According to World Health Organization, organ donation is defined as materials donated from deceased (cadaver) and living donors. In contrast, organ transplantation is the transfer of human organs from a donor to a recipient to restore functions in the body (1). According to Cambridge Dictionary, an organ donor is defined as a person who permits to take a part of their body either when they are alive or dead and put it into someone else's body to replace the malfunctioning organ (2). For patients with end-stage organ failure, organ transplantation is a last resort, according to Malaysia's Ministry of Health in collaboration with the Malaysian Department of Islamic Development (JAKIM). The method used to determine whether or not an organ transplant is permissible is based on the urgency with which the patient's life must be saved. To put it another way, organ transplantation is only performed in the direst of circumstances. Organ transplantation has a significant impact on the patient's life (3).

The terms' donation and transplant have different meanings. Organ donation is a living person allows others to use part of the tissues and organs for medical purposes after the person is dead and the patient is willing to donate, while organ transplant is an event of transporting a solid new organ taken from a living donor or cadaver instead of a nonfunctional organ in the body (4). The organs that can be donated include the heart, intestines, kidneys, liver, lungs, and pancreas. For patients with terminally ill organs, organ donation is one of the most common treatments they seek. Reducing comorbidity and improving transplant patients' overall quality of life is a significant benefit from organ transplantation (Error! Reference source not found.).

Animal kidney transplantation has been practised since prehistoric times by a Hungarian surgeon named Dr. Ulman in Vienna in 1992. Afterwards, Dr. Voronov carried out cadaveric kidney transplantation in the Soviet Union. As a result of this failure, kidney transplantation was not possible. The success of organ transplantation in the United States in the 1950s accelerated research into the field. Consequently, tissue and organ transplantation became a normal part of medical practice (4). Organ transplantation started in Malaysia in the 1970s; however, the procedure has only been actively performed since 1997, when the National Transplant Centre was set up at Hospital Kuala Lumpur. In December 1975, Malaysia's first kidney transplant was performed (5). More than 119,000 patients in the United States of America (USA) were eligible for a solid organ transplant in 2016, but only a quarter of those patients received an organ (6). In Malaysia, dialysis was used to treat kidney failure patients in latestage (7). In 2010, the total was 22939 of Malaysian patients, a massive increase from 2009 (8), and some of them need kidney transplant to live healthier than others. Only 38 Malaysians donated their organs in 2010, which equated to 1.4 organs per million Malaysians (3). This statistic may reflect Malaysian people's poor awareness and readiness to donate organs. Does their understanding of organ donation inhibit or exhibit them from donating the organ? The willingness of Malays (20.7\%) to donate organs was found to be lower than that of Chinese (36.6\%) and Indians (51.4 percent ) based on the study conducted in 2011 (9). Ministry of Health Malaysia and the National Transplant Resource Centre of Malaysia are two essential bodies in promoting awareness to the public with organ donation. In Malaysia, Malays are dominantly Muslim. Therefore, does religion stand on organ donation influence people from embarking on this activity? Since Islam is a way of life and provides a concrete guideline in organ donation activity, this study aims to explore organ donations' understanding, particularly among Muslims in Kuantan. The finding of this study can enhance and improve the promotion strategies led by authorities.

\section{METHODS}

\section{Study design and participants}

The researcher carried out a qualitative study design. This study investigated the perspectives of Malaysian Muslims between December 2020 and January 2021 in Kuantan. The interview was conducted through phone calls due to the Covid-19 outbreak. Participants were recruited through purposive sampling. The researcher identifies the potential respondent by looking at the list of member's groups in Facebook Group 'Warga Kuantan'. The inclusion and exclusion criteria apply in 
this identification and selection process. The inclusion criteria were that participants must be Muslim between 18 years old until 60 years old, participants must live in Kuantan, and participants willing to participate in the study. Participants who do not have any mobile phones would be excluded. The researcher approaches them, explains the project, and gets permission to have their mobile phone number. Respondents' verbal consent was taken before proceeding with the interview. All participants verbally agree to embark on this study. The data-saturated reached the eighth participant.

Kulliyyah of Nursing Postgraduate and Research Committee (KNPGRC) and International Islamic University Malaysia Research Ethics Committee (IREC) gave this study's ethical approval. Confidentiality was assured by using a pseudonym instead of real names. All audio recordings and transcripts were saved on a password-protected computer.

\section{Procedures}

Semi-structured, in-depth telephone interviews were done at a time convenient for participants. With participant permission, all interviews were audio-recorded. A broad data question was used, followed by an open-ended question to gain more explanation from the participants. The researcher's sample questions: a) Can you explain the term organ donation? b) Do you have any experience regarding organ donation? c) Do you know the current trend of organ donation in Malaysia? d) Why do you agree or disagree about organ donation? e) From where did you get the information about organ donation? f) Does Islam allow organ donation? Can you explain why?

The interview uses Malays language. The audio recordings were transcribed verbatim, and a copy of the transcribed is given to the participant to ensure no error in transcribing. The participants informed the researcher if any transcription did not reach the exact meaning of participants during the interview. All the interviews lasted for $45 \mathrm{~min}$.

\section{Data analysis}

The data has been analysed using deductive thematic analysis (Error! Reference source not found.). The process of thematic analysis is shown in Figure I: Coding process. Data analysis begins with an initial assessment of the data and a search for common themes. The researcher is responsible for transcribing the audio data because this study relies on audio recordings. The second step involves looking out for patterns or themes in existing codes. Moving from codes to themes is not necessarily a smooth or linear process. As the researcher becomes more and more familiar with the data, the researcher may find that they need to assign different codes or themes according to what new elements they find. In the third step, the researcher needs to make sure that the themes they've identified in the data are accurate and comprehensive, and that they can move on to the next step confident that they have accounted for all of the themes in their data. Label and finalise them as the last step in the process. The labels need to convey the theme's characteristics accurately.

Trustworthiness is ensured in this study. Trustworthiness can be divided into four concepts: credibility, transferability, dependability, and conformability (Error! Reference source not found.). First, to ensure the study's credibility, all progress and documents was well documented \& recorded. Starting form early of study until the end of study process, all activities, documents \& progress are well recorded and reported in writing in the appendix (audit trial). Purposive sampling was used to ensure participants were selected according to inclusion and exclusion criteria based on each objective. Each finding of the study was discussed with the team before producing the report. Second, the transferability is confirmed for this study because it can be done in another setting. After all, the information of research flow, including methodology, was thoroughly explained \& recorded (audit trial). Using purposive sampling to ensure participants were selected according to inclusion and exclusion criteria allows the study to be done in another setting using the same population. Third, dependability refers to the consistency and complete methodology with good research flow. There is continuity of study from the ethical application, data collection, data finding until the conclusion. The data is transparent and auditable. All documents, the process is well recorded in the appendix (audit trial). Last but not least, the conformability can see at all documents including transcription and data related interview well recorded and analyzed 
(audit trial) then, confirm the findings (themes) by the member and expert checking.

Figure I: Coding process

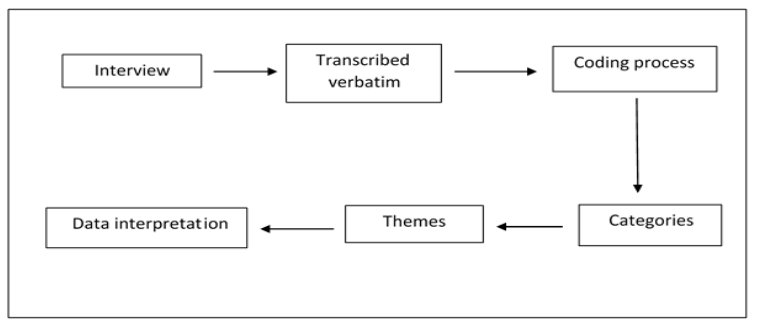

\section{RESULTS}

The sample involved eight participants. The data of the participants are shown in Table I. Six themes emerged from the interview session: a) understanding organ donation, b) decision factors on organ donation, $c$ ) view on-trend in Malaysia d) Islamic view opinion e) sources of information $\mathrm{f}$ ) promote awareness on organ donation. The themes were simplified into a diagram, as shown in Figure II.

Table I: Description of the participants

\begin{tabular}{ccc}
\hline Participant & Age & Gender \\
\hline $\mathbf{1}$ & 25 & Male \\
$\mathbf{2}$ & 23 & Male \\
$\mathbf{3}$ & 33 & Female \\
$\mathbf{4}$ & 24 & Male \\
$\mathbf{5}$ & 24 & Male \\
$\mathbf{6}$ & 23 & Male \\
$\mathbf{7}$ & 24 & Female \\
$\mathbf{8}$ & 24 & Female \\
\hline
\end{tabular}

Figure II: Summary of understanding on organ donation

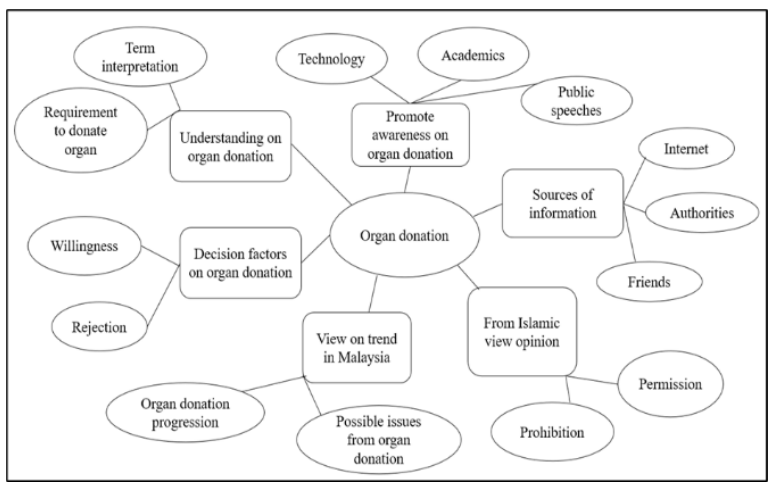

Understanding on organ donation
Participants generally agree that "donation" refers to a person giving their organs to another person. Organ donation can be performed both while the donor is still alive and when the donor has passed away.

In my opinion, organ donation is something that people do to donate. We give our organ to other people who need it (Participant 1)

We give our organ based on the agreement that we have made that we will donate our organ after we die (Participant 6)

Organ donation is a process where an internal organ is transferred from one body to another body. It is a process of taking an organ from a human body either alive or dead (Participant 3)

Organ donors must meet a basic standard before donating, according to the participants. Transplantation can only take place with the consent of the donor.

As for me who had registered to donate an organ after death also need to get permission from my next of kin. If they allow it then the process of donating can be done (Participant 6)

For a living person, they can give their permission, and for the dead, they can leave a will to tell the family members to donate the organ (Participant 1)

\section{Decision factors on organ donation}

Some factors identified that influence participants' decision making relates to organ donation. Some participants believe that donating an organ can help other people to live longer-the positive ideas on this influence their willingness to donate the organ.

Have the intention of saving others by donating organ (Participant 1)

We did no longer need our organ after death, and there is someone who needs our organ to survive. It also can be a good deed for us (Participant 6)

Some participants are reluctant to donate organs because they are concerned about their safety and the possible consequences of doing 
so. As a result, they reconsider their decision not to participate in organ donation because they lack sufficient information about the process.

We might be afraid our body will not function well after we donate our organ (Participant 3)

Do not have enough exposure about pro and cons if I am going to donate my organ (Participant 2)

\section{View on-trend in Malaysia}

The majority of participants are pleased with the campaign's efforts to raise awareness of organ donation. However, people still lack interest in taking part in organ donation activities.

People nowadays are more open to organ donation compared to previous. It may be because we had a better technology and exposure on social media has helped in the increase of this acceptance (Participant 1)

Malaysians are not widely exposed to organ donation. When they heard about this issue, they denied it and questioned why need to donate their organs. People do not see the benefits of organ donation. Malaysians are not aware of this issue (Participant 8)

More than half of the participants expressed concern about the illegal sale of organs.

Donating organ to gain profit and can lead to illegal activities such as organ sales or child kidnapping to selling their organs (Participant 1)

It can be the organ been used as a business to gain profit. I have read a person willing to sell his kidney to anyone needed so that he can gain money (Participant 4)

\section{Islamic view opinion}

The Muslim scholar's stance on organ donation influenced some participants' views. They believe that Islam permits organ donation.

Organ donation has no problem from an Islamic viewpoint because there is nothing said to prohibit an individual from donating (Participant 6)
I think it is a darurah for the people who require the organ, and we must assist in finding a donor, or we can be one (Participant 7)

Some participants, on the other hand, believe that Islam forbids people from removing anything from their bodies. It must be kept in good condition.

There is a saying that Islam prohibits us donating our organ because when we die, we need to be in perfect condition. Allah had given us complete and perfect, so we must return in that way (Participant 3)

\section{Sources of information}

Information about organ donation can be found on the internet. A simple search in a browser's search box is all they need to do.

All I know through reading from the internet but a reliable source such as government website (Participant 1)

Nowadays it has become modern. We can google all the information (Participant 3)

The government agencies are a reliable and trusting platform to receive accurate information about organ donation. The fake news, inaccurate information and unclear fact can be avoided.

A reliable source that can be referred from a religious authority like Jabatan Kemajuan Islam Malaysia or government agency in health like Ministry of Health (Participant 1)

We can get the information from any hospitals, clinics and by asking the doctors (Participant 2)

In order to get the information faster, close friends who have knowledge and experience would share the input anytime.

I have a conversation with my friend who is an end-stage kidney failure patient (Participant 5)

\section{Promoting awareness of organ donation}

Most participants believe technology usage to the maximum level would benefit people getting information faster. The academic 
platform needs to strategise the educational system to ensure that the students are aware of organ donation since their kid age. More public speeches discussing openly organ donation should be organised to ensure more people gain information.

People nowadays really rely on the Internet, and I do not deny that social media is the most suitable platform. Maybe can do in writing, infographic, poster, video (Participant 4)

The most effective medium is social media. To strengthen it more, we can attach some cases, statistics, and experience from a patient who needs an organ (Participant 5)

It should be inserted into the learning syllabus. For me, education from primary school need to emphasise more humanity (Participant 2)

Campaign to explain to people why need to donate, what is the effect and ruling about organ donation so that people will be clear (Participant 3)

\section{DISCUSSION}

Organ donation is a noble practice. It is not new in Malaysia as it is a treatment method that has been accepted in our country. As the need for organ transplants grows, so does the number of pledgers who want to donate their organs in the event of their deaths. If a recipient's organ or tissue has failed or been damaged, the donor's organs or tissues can be transplanted into someone else in need. The recipient will be able to enjoy a better quality of life following transplantation (10). The participants of this study are well verse the general concept of organ donation. Donating organs needs someone to go through some processes. Donor registration forms are available at all government hospitals, district health departments, district health centres, and the Transplant Resource Center for those who wish to donate their organs. The most important thing is, the donor must not suffer from infectious diseases such as HIV- AIDS, hepatitis $B$ and $C$, and syphilis. For those under 18 years, written permission from parents is required (8). Surprisingly, most participants of this study do not aware of this process.
Underlying factors exhibiting or inhibiting someone to being a part of donators is different from one to another. Some people believe donating an organ is a noble activity that God would reward. Saving people lives is regarded as a warrior by God. In chapter 5 of the Qur'an, verse 32, God highlighted, “..and if anyone saved a life it would be as if he saved the life of the whole people..". To put it another way, organ donation allows those in need to live on.

With regard to this, in the words of Dr. Yusuf al-Qaradawi, donating parts of a deceased person's body does not infringe on the deceased's dignity (3). This motivation verse encourages pious Muslims to seek God's attention by donating their organs and saving others' lives. On another side of the coin, some people worry about adverse effects after donating the organ like living with one kidney for the whole life and having risk of infection. The worrisome demotivate them to register as living donors. Besides, some recipients also feel worried to undergo operation since it matters of life and death. Since 1970, more than 270,000 kidney transplants have been performed in adults, making it one of the most successful procedures of all time. A liver transplant recipient is more likely to survive for seven years than a patient on the waiting list (11). One of the most extreme cases reported to date for the donors is that of a liver from a 93 years old donor transplanted into a 19-yearold recipient, who was still alive and without major complications (11).

Concerning the participant's awareness of current issues related to organ donation in Malaysia, they limit the scope to two only, awareness campaign and organ trading. In the former, many campaigns have been organised by government and private agencies to encourage people to register as donors. Information and registration counter set up at Hospital Serdang on the World Kidney Day, exhibition and registration counters set up by Hospital Kuala Lumpur at the Putra World Trade Centre. Official launching of the Media Campaign on Organ Donation 2008/2009 by YBhy Tan Sri Lee Lam Thye, Chairman of the Public Awareness Action Committee, was the impactful campaign done for the past 14 years (10). Although awareness campaigns appear to be the most effective means of influencing actual donor registration and willingness, the 
cost is prohibitive to run the campaign (12). The latter, a Malaysian, was reportedly involved in organ trafficking by luring poverty-stricken victims worldwide to sell their organs and operated in Manila, Philippines. An initial fee of $£ 55,000$ for the kidney and an additional payment of $£ 65,000$ to the clinic were cited in the report (13).

Furthermore, in the perspective of law, some debate arises on the right of the potential live donor. Only cadaveric donors are covered by the Human Tissues Act 1974, whereas live donors are covered by the common law. Consider the "opting out" system, in which everyone is assumed to be a donor until they express their displeasure. However, this system can only be fair if everyone in the community is aware of the law and understands its consequences. A simple and effective method of registering objections is needed for the system to function (14).

Religious concerns can be an obstacle to organ donation; religious leaders from all major religions and their edicts support organ donation (15). Even though the religion, like Islam, has provided clear guidelines on the permissibility and limitation of organ donation, some people still misinterpret and misconception that leads them to avoid being a donor. Focus group discussions in the previous study discovered that although organ donation is perceived as a good thing, misconception, cultural myths, and ethnic sensitivities were important factors limiting organ donation (16). In this study, the participant believes that God prohibits Muslims from donating organs as they must be in perfect condition hereafter. This indicated one of the misconceptions of the Islamic view on organ donation. A survey of 800 Malaysians found that 30 percent of them were unsure if organ donation was permitted or prohibited by Islam (17). Organ donation is not made because of any malicious intent or beneficial purposes. These acts are performed as a final resort to save the lives of patients who require organs. In the aim of Shari'ah, any conduct that is deemed ethical or permissible must fulfil its five purposes: preservation of religion, preservation of health, preservation of progeny, preservation of intellect, and preservation of wealth (18). Therefore, preserving health or life by donating organ to someone else in need is one of the elements in maqasid al-syar'iyyah or the purposes of Islamic law. The act of donating organs while someone is alive or after his death does not mean that the person is violating the trust and rights of his body because the organ donor does not mutilate his body intentionally.

On the contrary, the act of donating organs is made with good intention that is to save other people's lives (3). The National Fatwa Council, which sat on 23rd and 24th June 1970 (19), deliberated on organ transplantation, specifically eye and heart transplants. The Council decided that eye and heart transplants from cadaveric donors to living recipients are permissible in Islam, under the following considerations:

(i) It is carried out in critical and crucial situations where the recipient's life depends on the organ transplantation, and the transplantations have a high degree of success. (ii) In heart transplantation, the donor's death must first be ascertained.

(iii) Necessary actions must be taken so that no human killing and organ trading is involved.

(iv) Permission must be obtained from the donors prior to transplantation (in cases of normal death) or from the family members (in cases of death resulting from accidents).

The permissibility of donating and transplanting organs is also bound to the following conditions to protect all interests under Islamic law. These are:

(i) Living donors are not inflicted with harm such as death or disabilities (loss of hearing, sight, and mobility).

(ii) Transplantation is performed with permission from the donors.

(iii) The permission is obtained from donors who are legally able to do so as children cannot give such permission, mentally incompetent people, or individuals who are confused, under pressure or coerced to donate.

(iv) Not conducted in ways that could violate human dignity, such as organ trading. It should be done for altruistic reasons.

(v) Doctors involved in the transplantation have sufficient knowledge to assess the donors' and recipients' conditions based on the principles of maslahah (benefits) and mafsadah (harms) according to Islamic law (3).

\section{Limitation}


Our method of selecting participants is not the ideal sampling method among the Kuantan population. Furthermore, a person's unwillingness to participate would confound any sampling method, and we chose not to give any incentive for participation, but only willing subjects were enrolled. For future study recommendations, first, the recruitment of participants must be categorised into two groups; had registered as donors and never registered as a donor. Two different views of participants concerning organ donation will be identified. Second, due to the Covid-19 pandemic, the only platforms we have were phone calls and online meetings. The unstable internet connection of the researcher and participants themselves forced the study to be conducted via phone call.

\section{CONCLUSION}

Organ donation is a topic on which a great deal of people is informed. There are many misconceptions and anxieties that prevent people from signing up as a donor. As a result of awareness campaigns, family and friends can all have a positive influence on organ donation. The Islamic view on organ donation should be conveyed to the public in an easy-tounderstand manner by religious leaders.

\section{CONFLICT OF INTEREST}

The authors acknowledge that the publishing of this paper does not have any conflict of interest.

\section{REFERENCES}

1. WHO. Transplantation [Internet]. 2021 [cited 2021 Dec 6]. Available from: https:/ / www.who.int/healthtopics / transplantation\#tab=tab_2

2. Cambridge Dictionary. organ donor. Cambridge University Press 2021. 2021.

3. MOH. Organ Transplantation From the Islamic Perspective [Internet]. Ministry of Health Malaysia \& JAKIM; 2011. 40 p. Available from: www.moh.gov.my

4. Çetin G, Turgut M, Kaçar H. High School Students' Knowledge and Attitudes of Organ Donation and Organ Transplantation. Procedia - Soc Behav Sci [Internet]. 2014;116:2813-8. Available from: http:/ /dx.doi.org/10.1016/j.sbspro.2014. 01.662

5. Robson N. Organ Transplants: Ethical, Social, and Religious Issues in a Multicultural Society. SSRN Electron J. 2012;

6. Ahmed M, Kubilis P, Padela A. American Muslim Physician Attitudes Toward Organ Donation. J Relig Health [Internet]. 2018;57(5):1717-30. Available from: https://doi.org/10.1007/s10943-0180683-2

7. Saminathan TA, Hooi LS, Mohd Yusoff MF, Ong LM, Bavanandan S, Rodzlan Hasani WS, et al. Prevalence of chronic kidney disease and its associated factors in Malaysia; Findings from a nationwide population-based cross-sectional study. BMC Nephrol. 2020;21(1):1-11.

8. MOH. Organ Donation \& Transplantation. Pusat Sumber Transplan Nasional Kementerian Kesihatan Malaysia. 2021.

9. Wong LP. Knowledge, attitudes, practices and behaviors regarding deceased organ donation and transplantation in Malaysia's multi-ethnic society: A baseline study. Clin Transplant. 2011;25(1):22-31.

10. Azizul Khairi. Organ Donation [Internet]. Ministry of Health Malaysia. 2014 [cited 2021 Dec 7]. Available from: http:/ / www.myhealth.gov.my/en/orga n-donation-2/

11. Rana A, Godfre E. Outcomes in SolidOrgan Transplantation: 2019;46(1):75-6.

12. Burud IAS, Ghee LK, Tata MD. Knowledge, attitude and factors influencing public willingness towards organ donation among hospital patients and relatives in negeri sembilan, Malaysia. Med J Malaysia. 2020;75(3):260-5.

13. The Star. Malaysian allegedly involved in organ trafficking, says report. Star Media Group Berhad [Internet]. 2020 Aug; Available from: https:/ / www.thestar.com.my/news/nati on/2020/08/09/malaysian-allegedlyinvolved-in-organ-trafficking-says-report

14. Kassim PNJ. Organ transplantation in Malaysia: a need for a comprehensive legal regime. Med Law. 2005;24(1).

15. Oliver M, Woywodt A, Ahmed A, Saif I. Organ donation, transplantation and religion. Nephrol Dial Transplant. 2011;26(2):437-44. 
16. Wong LP. Factors Limiting Deceased Organ Donation: Focus Groups' Perspective From Culturally Diverse Community. Transplant Proc [Internet]. 2010;42(5):1439-44. Available from: http://dx.doi.org/10.1016/j.transproceed .2009.11.053

17. Tumin $\mathrm{M}$, Noh A, Tafran $\mathrm{K}$, NurulHuda MS, Abdullah N, Adnan WAHWM, et al. Muslims' views on the permissibility of organ donation: The case of Malaysia. Int e-Journal Sci Med Educ. 2016;10(1):41-6.

18. Ismail MFM, Shahadan SZ. Towards Maqasid al-Shari' ah Based Nursing Ethics. Int J Care Sch. 2021;4(2):2-7.

19. JAKIM. Derma Organ - Pemindahan Jantung Dan Mata. Putrajaya: JAKIM; 2021. 